\title{
Evaluation of Potato Varieties Grown in Hydroponics for Phosphorus Use Efficiency
}

\author{
Wei-Chieh Lee ${ }^{1}$, Lincoln Zotarelli ${ }^{1}$, Diane L. Rowland ${ }^{2}$ and Guodong Liu ${ }^{1, *(1)}$ \\ 1 Horticultural Sciences Department, University of Florida, Gainesville, FL 32611, USA; \\ lwc76625@gmail.com (W.-C.L.); lzota@ufl.edu (L.Z.) \\ 2 Agronomy Department, University of Florida, Gainesville, FL 32611, USA; dlrowland@ufl.edu \\ * Correspondence: guodong@ufl.edu; Tel.: +1-352-273-4814
}

Citation: Lee, W.-C.; Zotarelli, L.;

Rowland, D.L.; Liu, G. Evaluation of Potato Varieties Grown in Hydroponics for Phosphorus Use Efficiency. Agriculture 2021, 11, 668. https://doi.org/10.3390/

agriculture11070668

Academic Editor: Markku Yli-Halla

Received: 20 June 2021

Accepted: 13 July 2021

Published: 15 July 2021

Publisher's Note: MDPI stays neutral with regard to jurisdictional claims in published maps and institutional affiliations.

Copyright: (c) 2021 by the authors. Licensee MDPI, Basel, Switzerland. This article is an open access article distributed under the terms and conditions of the Creative Commons Attribution (CC BY) license (https:/ / creativecommons.org/licenses/by/ $4.0 /)$.

\begin{abstract}
Global phosphate mineral resources are nonrenewable and are inevitably depleting. Exploiting elite varieties has become imperative for the efficient use of phosphorus $(\mathrm{P})$ for sustainable crop production. Three potato varieties were hydroponically evaluated for P mobilization, uptake, and utilization efficiencies at different $P$ levels and sources during $28 \mathrm{~d}$ seedling growth. 'Harley Blackwell', 'La Chipper', and 'Red LaSoda' were selected from a previous study and grown in modified Hoagland solution, with different $\mathrm{P}$ concentrations of soluble high $\mathrm{P}$ as $\mathrm{NaH}_{2} \mathrm{PO}_{4}\left(10 \mathrm{mg} \mathrm{L}^{-1} \mathrm{P}\right)$, soluble low $\mathrm{P}\left(1 \mathrm{mg} \mathrm{L}^{-1} \mathrm{P}\right)$, and $286 \mathrm{mg} \mathrm{L}^{-1}$ sparingly soluble $\mathrm{P}$ as tri-calcium phosphate [TCP, $\mathrm{Ca}_{3}\left(\mathrm{PO}_{4}\right)_{2}$ ] with $2286 \mathrm{mg} \mathrm{L}^{-1} \mathrm{CaSO}_{4}$. 'Harley Blackwell' and 'La Chipper' had significantly greater biomass than 'Red LaSoda' in the low P or TCP treatments. In low-P stress, P utilization efficiency was significantly greater for 'Harley Blackwell' than that of the other two varieties. 'Red LaSoda' was more efficient in P mobilization from TCP as compared to the other two cultivars. The holistic score analysis indicated that 'Harley Blackwell' was the most P-efficient while 'Red LaSoda' was the least P-efficient. The results of this study show that the TCP solution was successful for screening P-efficient potato varieties.
\end{abstract}

Keywords: Solanum tuberosum L.; low-phosphorus stress; phosphorus bioavailability; buffered low-P hydroponics

\section{Introduction}

Along with nitrogen $(\mathrm{N})$ and potassium $(\mathrm{K})$, phosphorus $(\mathrm{P})$ is one of the three main nutrients essential for plant growth and development. Due to the necessity of increasing crop production to meet the food needs of the growing world population, it is predicted that P consumption will increase by 3 to $4 \%$ annually in the next few decades [1]. Agricultural demand of $\mathrm{P}$ for crop production is expected to increase from $51 \%$ to $86 \%$ by the year 2050 . Global fertilizer $\mathrm{P}$ inputs for crop production will increase from $14.5 \mathrm{Tg} \mathrm{P} \mathrm{yr}^{-1}$ in 2005 to 22 27 $\mathrm{Tg} \mathrm{yr}^{-1} \mathrm{P}$ in 2050 [2]. There is a concern that the world P rock resources could be quickly depleted in decades [3] and the world could face a potential P crisis [4]. Recent estimates show that world P rock may not run out soon [5]. However, phosphate resources are limited and nonrenewable and are gradually depleted due to increased use. Therefore, alternate strategies to enhance P-use efficiency by major crop plants, including potato (Solanum tuberosum L.), are of critical necessity to continue to increase food production. Exploring cultivars for increased P-use efficiency is an effective breeding strategy. P-use efficiency of potato is defined as tuber yield increase per unit of $\mathrm{P}$ fertilizer applied and is most related to cultivar, $\mathrm{P}$ source, $\mathrm{P}$ application time, $\mathrm{P}$ replacement, the quantity of $\mathrm{P}$ application, soil, rainfall/irrigation, crop management, etc. [6]. P uptake efficiency refers to the portion of the $\mathrm{P}$ taken up by the crop per unit of $\mathrm{P}$ added. The uptake efficiency of applied P fertilizer is usually less than $20 \%$ for the season following P application [7]. There is, obviously, much room to improve the crop's uptake efficiency. After long-term cultivation, a substantial portion of the $\mathrm{P}$ applied is accumulated in the soil, usually fixed 
by aluminum and iron in acidic soils and calcium and magnesium in alkaline soils. Our recent study conducted across 32 commercial potato farms in northeast Florida showed that the mean Mehlich 3 extractable P was 351 (range: $81-599$ ) $\mathrm{mg} \mathrm{kg}^{-1}$ in root zone soil [8]. This $\mathrm{P}$ level is almost 7 -fold greater than the recommended adequate $\mathrm{P}$ level $\left(45 \mathrm{mg} \mathrm{kg}^{-1}\right)$ for potato production [9].

The main reason for applying $\mathrm{P}$ fertilizers on P-rich soil is that potato is a high nutrient demanding crop as compared to other major crops [10-13] for several reasons: (1) because potato has low root density, a shallow root system [14], which is limited to the top $30 \mathrm{~cm}$ soil [10]; (2) soil temperatures are generally low at the beginning of the potato growing season in Florida, hence soil P bioavailability may be limited; (3) optimal temperature for potato root growth and development is $20^{\circ} \mathrm{C}$ [15]. This optimal temperature is reached only in February and early March; (4) Phosphate is easily immobilized due to high aluminum (Al) content and Florida soils are typically sandy with inherently high Al content [8], with soil $\mathrm{pH}$ ranging from 5.0 to 6.0 in the growing seasons in NE Florida; (5) Florida soils are fumigated every year which kills beneficial microbes that are required for $\mathrm{P}$ transformation from sparsely soluble phosphates into bioavailable P.

Elite cultivars are those that mobilize sparsely soluble phosphates into bioavailable P. The mobilization of sparsely soluble phosphates allows cultivars to utilize P resources in the soil and have the potential to reduce dependence on P fertilization. Given low$\mathrm{P}$ bioavailability, P-efficient varieties can acclimate to these sub-optimal conditions by increasing their root-shoot ratio, i.e., producing more roots, $[16,17]$ which enables these plants to extract $\mathrm{P}$ from larger soil volumes, as reported in other crops such as rape (Brassica napus subsp. napus L.), wheat (Triticum aestivum L.), barley (Hordeum vulgare L.), and rice (Oryza sativa L.) $[3,16,17]$. A mechanism of acclimation to low-P soils with insoluble tri-calcium phosphate $\left[\mathrm{TCP}, \mathrm{Ca}_{3}\left(\mathrm{PO}_{4}\right)_{2}\right]$ is to increase Ca uptake, which results in enhancing phosphate solubility [18-21]. However, the literature shows that knowledge is limited about the acclimation capability in potato or P-use efficiency of the potato cultivars grown in Florida [22-24].

Tri-calcium phosphate is a sparsely soluble $\mathrm{P}$ source. There is a chemical equilibrium in the solution after this sparsely soluble $\mathrm{P}$ source is put into water. There are two types of mutual accompanying ions released from the $\mathrm{P}$ source: cations, $\mathrm{Ca}^{2+}$ ions and anions, $\mathrm{PO}_{4}{ }^{3-}$ ions. The product of the molar concentrations of the two types of ions is the solubility product, i.e., $\mathrm{K}_{\mathrm{sp}}$ of TCP. Based on the $\mathrm{K}_{\mathrm{sp}}$ of TCP, when $\mathrm{Ca}^{2+}$ ions are removed from the system, e.g., absorbed by plants, more TCP is dissolved and, hence, plants are provided with more bioavailable $\mathrm{P}$. Tri-calcium phosphate has a small $\mathrm{K}_{\mathrm{sp}}$ of $2.07 \times 10^{-33}$ [25] and was used for simulating the low soil $\mathrm{P}$ bioavailability in the growth medium of this study. Bioavailability of $\mathrm{P}$ released from TCP varies with Ca levels. For example, after adding $\mathrm{CaSO}_{4}$ to a TCP solution, the $\mathrm{Ca}$ ions from the added $\mathrm{CaSO}_{4}$ precipitate most of the $\mathrm{P}$ released from TCP. This precipitation limits the bioavailable $\mathrm{P}$ concentration to only $35 \mu \mathrm{g} \mathrm{L}^{-1}$ because of the dynamic equilibrium between TCP and $\mathrm{CaSO}_{4}$. This low$\mathrm{P}$ concentration was buffered because TCP continued releasing bioavailable $\mathrm{P}$ as it was depleted due to plant uptake. If TCP is used with no supplemental $\mathrm{Ca}$, a cultivar with high Ca uptake promotes increased $P$ release, and is considered as P-efficient. As companion cations in TCP, Ca ions are absorbed by plants, stoichiometrically, at a rate equivalent to $\mathrm{P}$ release. The greater the Ca uptake, the more P-efficient the cultivar is. Therefore, if a cultivar increases Ca uptake when grown in a solution with TCP, this results in increasing $\mathrm{P}$ bioavailability leading to enhanced P-use efficiency by the cultivar. TCP is often used as an insoluble P source in nutrient solutions to simulate low but buffered P bioavailability in the soil solution, and to evaluate P mobilization ability of crop germplasm [26,27].

Identifying P-efficient potato varieties can facilitate selection of those elite cultivars that tolerate low-P stress and produce a commercially viable harvest. Since biomass production, $\mathrm{P}$ mobilization, $\mathrm{P}$ uptake, and $\mathrm{P}$ utilization efficiency are the main factors that impart tolerance to low-P stress in potato [28]; it may be useful to use a score that combines the quantitative measurements of these traits in selection efforts. A new concept 
of a holistic score (HS), which integrates P uptake rate, P utilization efficiency, and biomass, was used to evaluate hybrid rice varieties for K use efficiency [29]. This concept may also be useful for identifying P-efficient potato varieties. The mathematical definition is given in the section of materials and methods below.

The objectives of this study were to: (1) compare variability in P uptake, mobilization, and utilization of TCP with the typical P-efficient and P-inefficient varieties selected from a previous study [30] and (2) test a HS method that combines different traits into one index evaluating potato varieties for P-use efficiency.

\section{Materials and Methods}

\subsection{Potato Seeds}

Certified potato seed pieces (20-25 g/piece) of 'Harley Blackwell', 'La Chipper', and 'Red LaSoda' were obtained from the US Department of Agriculture-Agricultural Research Service, Beltsville, MD, USA.

\subsection{Growth Conditions}

This experiment was conducted in a glasshouse at UF/IFAS Plant Science Research and Education Unit, in Citra, FL, USA. A completely randomized design was used with six replications (one pot per replication). Fifty potato seed pieces were individually placed in 5-cm Mesh Net Cups and covered with Hydroton Original Clay Pebbles. The seed pieces were grown in aeroponics in a modified Hoagland solution with the following composition (mg L ${ }^{-1}$ ): $\mathrm{NO}_{3}-\mathrm{N}, 160 ; \mathrm{NH}_{4}{ }^{+}-\mathrm{N}, 12 ; \mathrm{K}, 239 ; \mathrm{Ca}, 152 ; \mathrm{Mg}$, 38.2; $\mathrm{S}, 40 ; \mathrm{Fe}, 1.68 ; \mathrm{Cu}, 0.24 ;$ Mo, $0.128 ; \mathrm{Mn}, 1.25 ; \mathrm{Zn}, 0.6 ; \mathrm{B}, 0.8 ; \mathrm{Si}, 10, \mathrm{pH} 6.5$ [31]. The seed pieces were carefully removed from the seedlings to avoid the nutrition differences when the seedlings had 4-6 leaves including unfolded ones. Because seedlings, even from the same potato tuber, were variable in growth, the seedlings were classified into six groups, serving as the six replications according to seedling size for error control. Thirty-six healthy seedlings were chosen from aeroponics. Two seedlings were transplanted and grown as 2 seedlings per plastic container of $1750 \mathrm{~mL}$ filled with the above nutrient solution. Oxygen was supplied by adding $100 \mu \mathrm{L}$ of $3 \% \mathrm{H}_{2} \mathrm{O}_{2}$ twice a week. The treatments included: (i) $10 \mathrm{mg} \mathrm{L}^{-1} \mathrm{P}$ as sodium dihydrogen phosphate $\left(\mathrm{NaH}_{2} \mathrm{PO}_{4}\right.$, Control), (ii) $1 \mathrm{mg} \mathrm{L}^{-1} \mathrm{P}$ as $\mathrm{NaH}_{2} \mathrm{PO}_{4}$ (Low $\mathrm{P}$ ), (iii) $286 \mathrm{mg} \mathrm{L}^{-1}$ laboratory grade TCP $+2286 \mathrm{mg} \mathrm{L}^{-1}$ laboratory grade $\mathrm{CaSO}_{4}$, i.e., with an initial $\mathrm{P}$ concentration of $35 \mu \mathrm{g} \mathrm{L}{ }^{-1}$. After 28 days, the seedlings were harvested, washed, and oven dried at $70{ }^{\circ} \mathrm{C}$ to a constant weight $(72 \mathrm{~h})$. Shoots and roots were weighed separately.

\subsection{Analyses of P Content in Biomass}

The oven-dried plant biomass was milled to pass a 40-mesh stainless steel sieve, weighed (300 $\pm 50 \mathrm{mg})$ into porcelain crucibles, and placed in a Thermolyne Muffle Furnace (Model, FA1730, Dubuque, IA, USA). The temperature was increased at $10^{\circ} \mathrm{C}$ per min until $250{ }^{\circ} \mathrm{C}$ was reached, maintained for $30 \mathrm{~min}$, and then increased to $550{ }^{\circ} \mathrm{C}$ for $6 \mathrm{~h}$. The ash was cooled to room temperature and $2.25 \mathrm{~mL} 6 \mathrm{~N} \mathrm{HCl}$ was added; the mixture sat for $15 \mathrm{~min}$, then, filtered through No. 41 filter paper, and diluted to $50 \mathrm{~mL}$ with de-ionized water [31,32]. Phosphorus concentration was analyzed using automated colorimetry performed by a Discrete Analyzer (AQ2 SEAL Analytical, Hanau, Germany), based on US EPA Method 365.1 [33].

\subsection{Holistic Score}

Calculating a quantitative holistic score was formulated for the combined contributions of the three main components of a given potato variety's tolerance to low-P stress as follows [29].

$$
\mathrm{HS}=\left(\frac{A_{i}}{A_{m}}+\frac{E_{i}}{E_{m}}+\frac{B_{i}}{B_{m}}\right)\left(\frac{1}{3}\right) \times 100
$$


where HS is the holistic score of a potato variety, and $A_{i}, E_{i}$, and $B_{i}$ are the $\mathrm{P}$ uptake, the $\mathrm{P}$ utilization efficiency, and the amount of biomass produced by variety $i$, respectively. $A_{m}$, $E_{m}$, and $B_{m}$ are the mean values of the corresponding P uptake, $\mathrm{P}$ utilization efficiency, and biomass of variety $i$, respectively, and 3 is the number of the traits included in the evaluation.

After this study was completed, we continued an on-going field study in the main commercial potato production area from 2018 through 2021. 'Red LaSoda' was used for the large-scale field study, and in spring 2019, a field survey on symptoms of P deficiency was completed.

\subsection{Statistical Analyses}

The data were analyzed by two-way ANOVA with the variables of potato variety and $\mathrm{P}$ bioavailability in hydroponic solution. The interaction between potato variety and P bioavailability was tested by using Statistical Analysis software JMP version 10 (SAS Institute, Cary, NC, USA). The critical ranges $\left(\mathrm{LSD}_{0.05,2}\right)$ of Duncan's Multiple Range Test were used for identifying significant differences between the means [34]. The results were considered significant at $p<0.05$.

\section{Results and Discussion}

\subsection{Biomass and Root/Shoot Ratio}

Table 1 shows that root biomass was not influenced by either cultivar or P treatments. However, shoot biomass and total plant biomass were influenced by both the variables and their interaction. 'Red LaSoda' shoot biomass was 32 and $54 \%$ greater than that of 'Harley Blackwell' and 'La Chipper', respectively, in the control with adequate (10 $\left.\mathrm{mg} \mathrm{L}^{-1}\right)$ $\mathrm{P}$ treatments. However, with the $1 \mathrm{mg} \mathrm{L}^{-1} \mathrm{P}$ supply, the shoot biomass of 'Red LaSoda' was 49 and 33\% smaller than that of 'Harley Blackwell' and 'La Chipper', respectively. In the TCP treatment, the shoot biomass of 'Red LaSoda' was 67 and $20 \%$ smaller than that of 'Harley Blackwell' and 'La Chipper', respectively (Figure 1). As compared to the control, the reduction in the whole-plant (shoot + root) biomass in the $1 \mathrm{mg} \mathrm{L}^{-1} \mathrm{P}$ and TCP treatments was 27 and 33\% for 'Harley Blackwell', 18 and 32\% for 'La Chipper', and $74 \%$ and $73 \%$ for 'Red LaSoda', respectively. Reduction in whole-plant biomass is a common response to $\mathrm{P}$ deficiency, such as in rice [35]. The genotypic responses to varying $P$ bioavailability levels were an effective indication of genotypic differences in P-use efficiency (Figure 1).

Our results demonstrate that the three varieties evaluated in this study differed with respect to their response to different $P$ availability treatments. The interactions in $\mathrm{P}$ accumulation and in P-use efficiency between genotype and $\mathrm{P}$ bioavailability were also significant at $p<0.01$ (Table 1). The interactions can be explained by the genotypic differences in $\mathrm{P}$ uptake or accumulation (Figure 2) and P utilization (Figure 3). P-efficient varieties are effective in mobilization of insoluble phosphates and efficient in P uptake and P utilization, particularly in low-P stress.

The root-shoot ratio was greater in the low P and TCP treatments than in the control, across all three cultivars (Figure 4). In the $1 \mathrm{mg} \mathrm{L}^{-1} \mathrm{P}$ treatment, the root-shoot ratios of 'Harley Blackwell', 'La Chipper', and 'Red LaSoda' were greater by 86, 48, and 464\%, respectively, as compared to those of the control. The corresponding values for the TCP treatment were 129,69 , and $161 \%$. A plant with a larger root system can access greater quantities of bioavailable $P$ in the growth medium as compared to plants with a smaller root system [36]. The increase in root-shoot ratio is an important adaptive mechanism to low-P stress. 


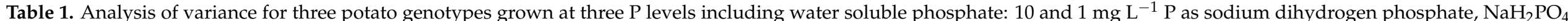

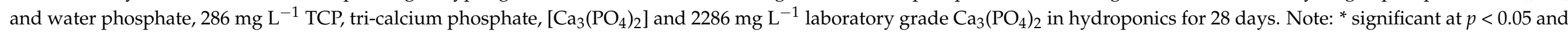
** significant at $p<0.01$.

\begin{tabular}{|c|c|c|c|c|c|c|c|c|c|c|c|c|c|c|c|c|c|c|c|}
\hline \multirow[b]{2}{*}{ Variable } & \multirow[b]{2}{*}{ DF } & \multicolumn{10}{|c|}{ Sum of Squares for Plant Dry Matter } & \multicolumn{8}{|c|}{ Sum of Squares for Phosphorus } \\
\hline & & $\begin{array}{c}\text { Shoot } \\
\text { (S) }\end{array}$ & F-Value & $\operatorname{Pr}>\mathrm{F}$ & $\begin{array}{l}\text { Root } \\
\text { (R) }\end{array}$ & F-Value & $\operatorname{Pr}>\mathrm{F}$ & $S+R$ & F-Value & $\operatorname{Pr}>\mathrm{F}$ & $\begin{array}{c}\text { R:S } \\
\text { Ratio }\end{array}$ & F-Value & $\operatorname{Pr}>\mathrm{F}$ & $\begin{array}{c}\text { Accumulation } \\
\text { (mg/Plant) }\end{array}$ & F-Value & $\operatorname{Pr}>\mathrm{F}$ & $\begin{array}{c}\text { Utilization } \\
\text { Efficiency (g/g) }\end{array}$ & F-Value & $\operatorname{Pr}>\mathrm{F}$ \\
\hline Genotype (G) & 2 & $25.7 *$ & 3.62 & $<0.05$ & 0.426 & 1.21 & 0.31 & $29.8^{*}$ & 3.3 & $<0.05$ & 0.0794 & 1.08 & 0.35 & $191.7^{* *}$ & 6.19 & $<0.01$ & $397,299 * *$ & 16.44 & $<0.01$ \\
\hline $\begin{array}{c}\text { Phosphorus (P) } \\
\text { level }\end{array}$ & 2 & $164.6^{* *}$ & 23.16 & $<0.05$ & 0.0202 & 0.11 & 0.95 & $160.8^{* *}$ & 80.4 & $<0.01$ & 0.3403 * & 4.62 & $<0.05$ & $1533.9^{* *}$ & 49.48 & $<0.01$ & $587,126^{* *}$ & 25.3 & $<0.01$ \\
\hline $\begin{array}{l}\text { GXP } \\
\text { Total }\end{array}$ & $\begin{array}{c}4 \\
55\end{array}$ & $\begin{array}{c}81.0^{* *} \\
462.8\end{array}$ & 5.7 & $<0.01$ & $\begin{array}{l}0.8809 \\
9.6916\end{array}$ & 1.25 & 0.3 & $\begin{array}{l}89.6^{* *} \\
517.9\end{array}$ & 4.97 & $<0.05$ & $\begin{array}{l}0.2228 \\
2.5145\end{array}$ & 1.51 & 0.21 & $\begin{array}{c}105.4^{*} \\
2712\end{array}$ & 3.22 & $<0.05$ & $\begin{array}{l}241,462 * * \\
1,758,437\end{array}$ & 4.99 & $<0.01$ \\
\hline
\end{tabular}




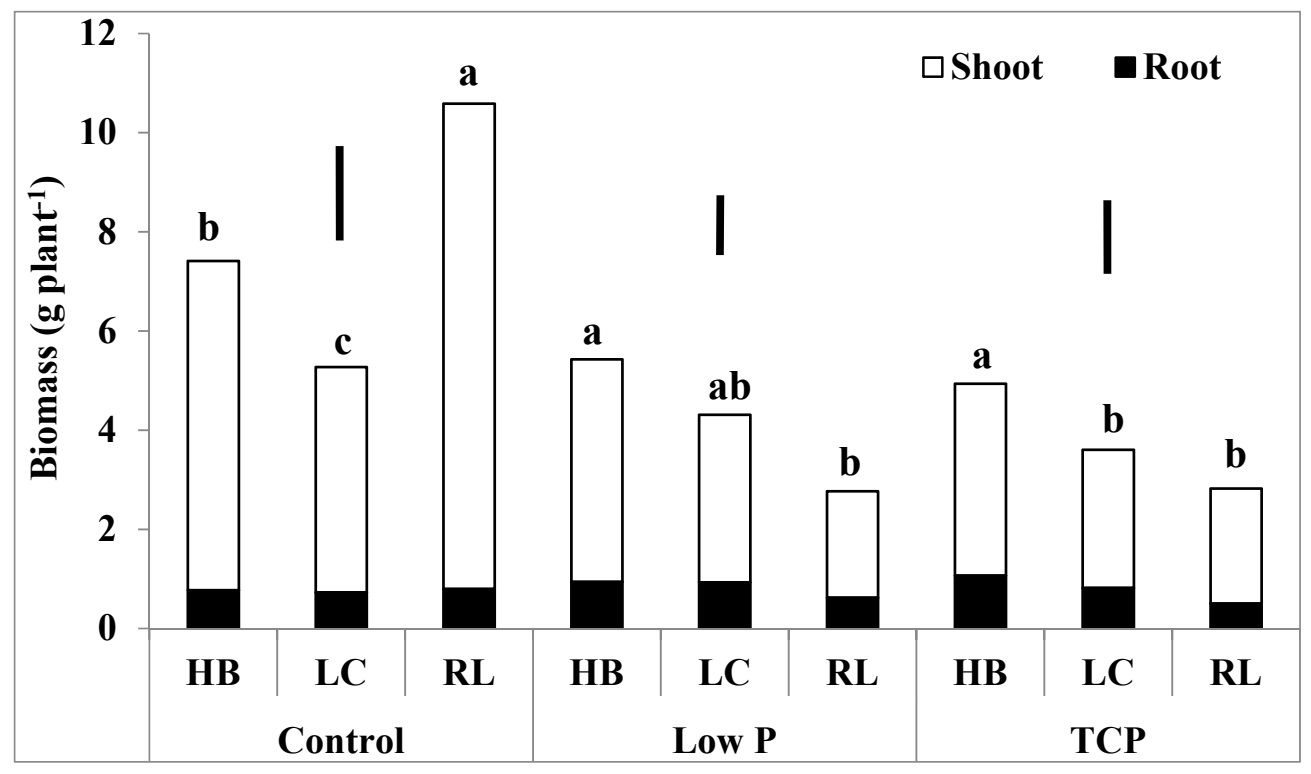

Figure 1. Total biomass of potato seedlings grown in modified Hoagland solution with different $\mathrm{P}$ bioavailabilities for 28 days. Histograms with different letters in the same treatment are different at $p<0.05$. Control: $10 \mathrm{mg} \mathrm{L}^{-1} \mathrm{P}$ water soluble $\mathrm{P}$ as $\mathrm{NaH}_{2} \mathrm{PO}_{4}$; Low P: $1 \mathrm{mg} \mathrm{L}^{-1} \mathrm{P}$ water soluble $\mathrm{P}$ as $\mathrm{NaH}_{2} \mathrm{PO}_{4}$; and $286 \mathrm{mg} \mathrm{L}^{-1}$ sparsely soluble $\mathrm{P}$ as TCP, tri-calcium phosphate, $\mathrm{Ca}_{3}\left(\mathrm{PO}_{4}\right)_{2}$ with 2286 mg L ${ }^{-1}$ laboratory grade. HB: 'Harley Blackwell'; LC: 'La Chipper'; RL: 'Red LaSoda'. The bars are the values of $\mathrm{LSD}_{0.05,2}$ for the plant biomass of the control, low $\mathrm{P}$ and TCP, respectively.

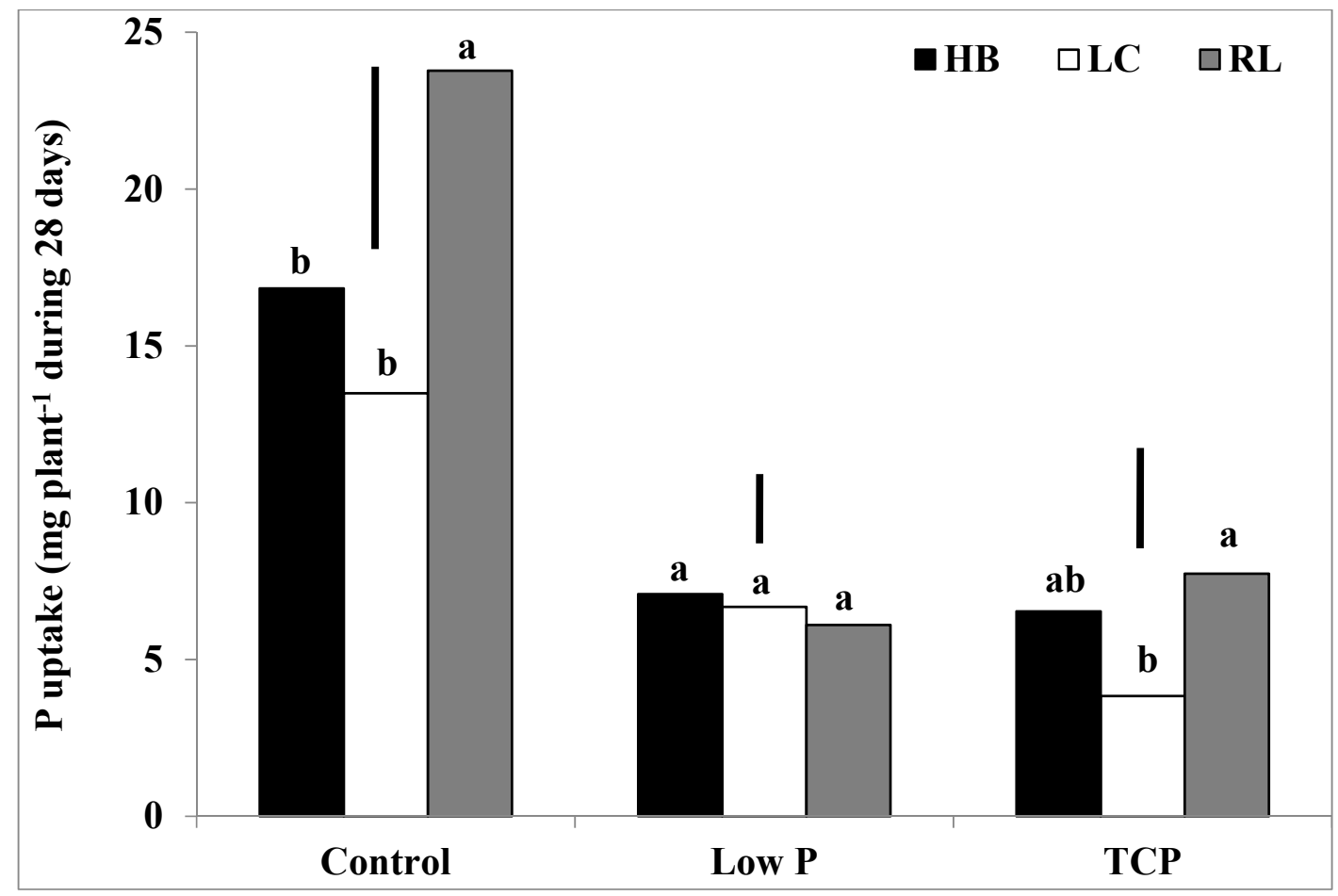

Figure 2. Phosphorus uptake in 28-days old potato seedlings grown in modified Hoagland solution with different $\mathrm{P}$ bioavailabilities. Histograms with different letters in the same treatment are different at $p<0.05$. Control: $10 \mathrm{mg} \mathrm{L}^{-1} \mathrm{P}$ as water soluble $\mathrm{P}, \mathrm{NaH}_{2} \mathrm{PO}_{4}$; Low P: $1 \mathrm{mg} \mathrm{L}^{-1} \mathrm{P}$ as water soluble $\mathrm{P}, \mathrm{NaH}_{2} \mathrm{PO}_{4}$; and $286 \mathrm{mg} \mathrm{L}^{-1} \mathrm{TCP}$, tri-calcium phosphate, $\mathrm{Ca}_{3}\left(\mathrm{PO}_{4}\right)_{2}$ as sparsely soluble $\mathrm{P}$ with $2286 \mathrm{mg} \mathrm{L}^{-1}$ laboratory grade $\mathrm{Ca}_{3}\left(\mathrm{PO}_{4}\right)_{2}$. HB: 'Harley Blackwell'; LC: 'La Chipper'; RL: 'Red LaSoda'. The bars are the values of $\mathrm{LSD}_{0.05,2}$ for the plant biomass of the control, low $\mathrm{P}$ and TCP, respectively. 


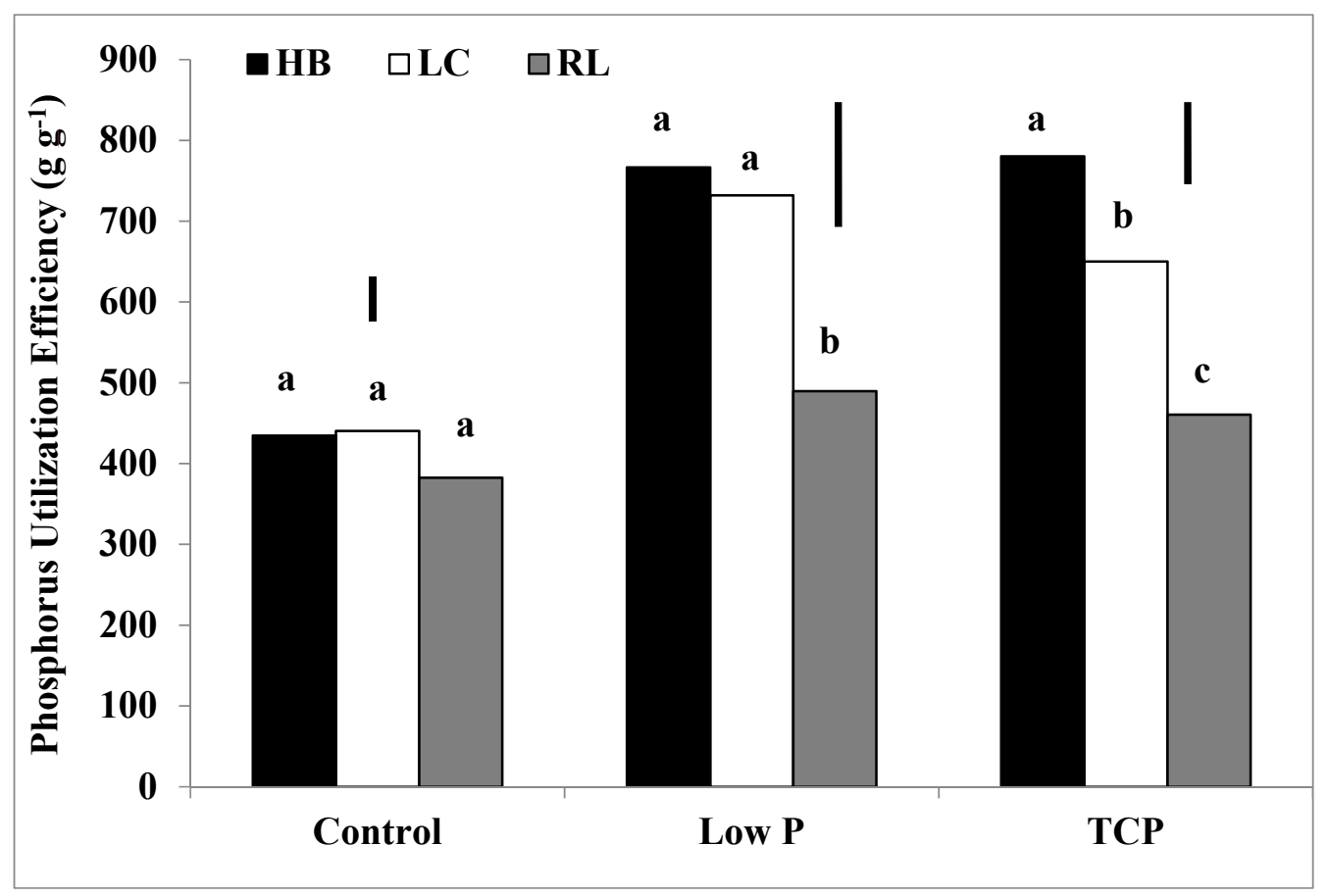

Figure 3. Phosphorus utilization efficiency of 28-days old potato seedlings grown in modified Hoagland solution with different $\mathrm{P}$ bioavailabilities. Histograms with different letters in the same treatment are different at $p<0.05$. Control: $10 \mathrm{mg} \mathrm{L}^{-1} \mathrm{P}$ as water soluble $\mathrm{P}, \mathrm{NaH}_{2} \mathrm{PO}_{4}$; Low P: $1 \mathrm{mg} \mathrm{L}^{-1} \mathrm{P}$ as water soluble $\mathrm{P}, \mathrm{NaH}_{2} \mathrm{PO}_{4}$; and $286 \mathrm{mg} \mathrm{L}{ }^{-1} \mathrm{TCP}$, tri-calcium phosphate, $\mathrm{Ca}_{3}\left(\mathrm{PO}_{4}\right)_{2}$ as sparsely soluble $\mathrm{P}$ with $2286 \mathrm{mg} \mathrm{L}^{-1}$ laboratory grade $\mathrm{Ca}_{3}\left(\mathrm{PO}_{4}\right)_{2}$. HB: 'Harley Blackwell'; LC: 'La Chipper'; RL: 'Red LaSoda'. The bars are the values of $\mathrm{LSD}_{0.05,2}$ for the plant biomass of the control, low P and TCP, respectively.

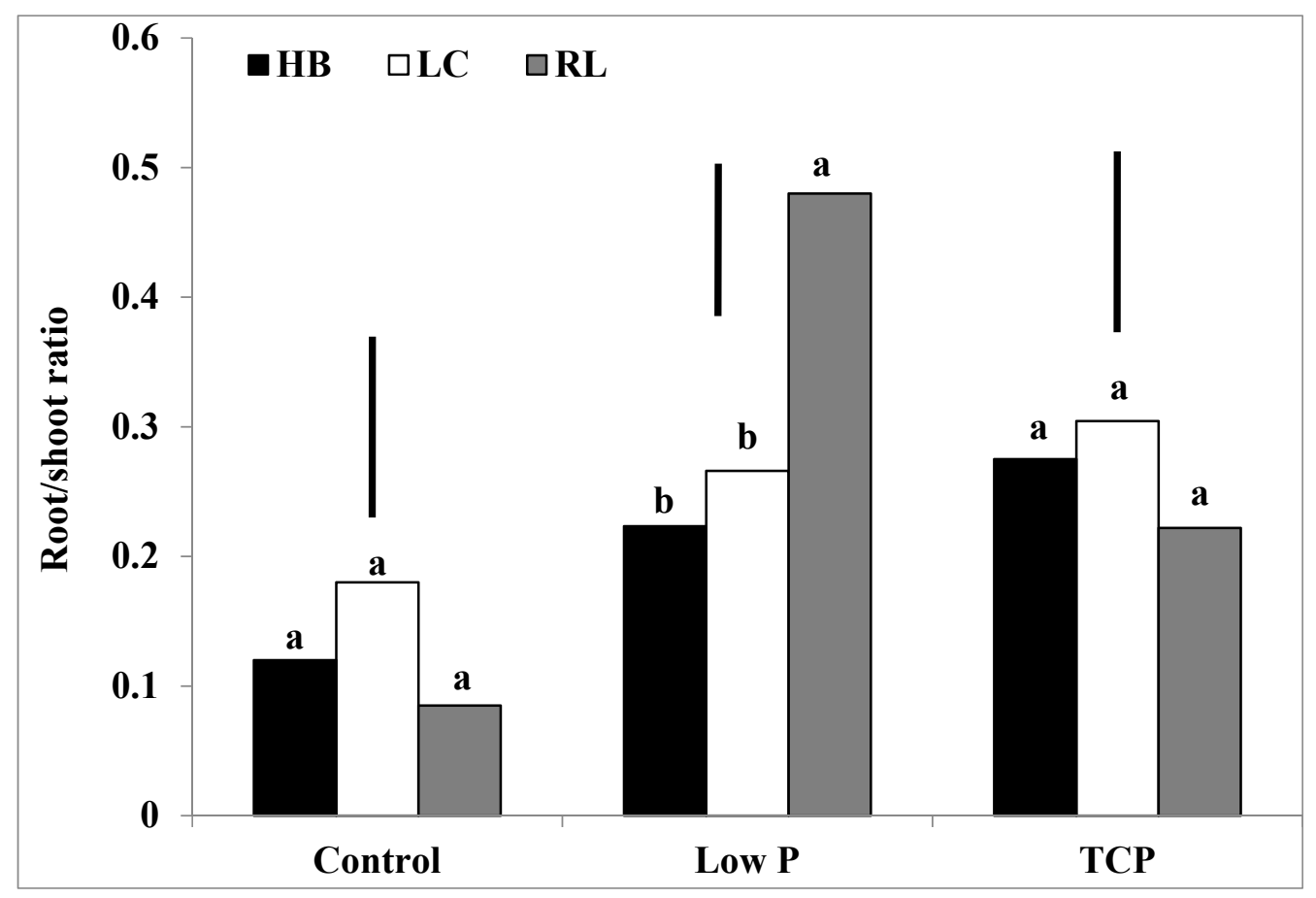

Figure 4. Root-shoot ratio of potato seedlings grown in modified Hoagland solution with different $\mathrm{P}$ bioavailabilities for 28 days. Histograms with different letters in the same treatment are different at $p<0.05$. Control: $10 \mathrm{mg} \mathrm{L}^{-1} \mathrm{P}$ as water soluble $\mathrm{P}, \mathrm{NaH}_{2} \mathrm{PO}_{4}$; Low P: $1 \mathrm{mg} \mathrm{L}^{-1} \mathrm{P}$ as water soluble $\mathrm{P}, \mathrm{NaH}_{2} \mathrm{PO}_{4}$; and $286 \mathrm{mg} \mathrm{L}^{-1} \mathrm{TCP}$, tri-calcium phosphate, $\mathrm{Ca}_{3}\left(\mathrm{PO}_{4}\right)_{2}$ as sparsely soluble $\mathrm{P}$ and $2286 \mathrm{mg} \mathrm{L}^{-1}$ laboratory grade $\mathrm{Ca}_{3}\left(\mathrm{PO}_{4}\right)_{2}$. HB: 'Harley Blackwell'; LC: 'La Chipper'; RL: 'Red LaSoda'. The bars are the values of $\mathrm{LSD}_{0.05,2}$ for the plant biomass of the control, low P and TCP, respectively. 


\subsection{Phosphorus Uptake}

In the control, the $\mathrm{P}$ supplied was a soluble $\mathrm{P}$ source, $\mathrm{NaH}_{2} \mathrm{PO}_{4}$, which was $100 \%$ bioavailable. Phosphorus uptake across the three varieties ranged from 13.5 to $23.8 \mathrm{mg}$ per plant during the 28 days duration of this study. P uptake in 'Red LaSoda' was greater $(p<0.05)$ than the other two cultivars. In the $1 \mathrm{mg} \mathrm{L}^{-1} \mathrm{P}$ treatment, the $\mathrm{P}$ supplied was available but was too limited. Upon uptake of the limited amount of $\mathrm{P}$, no additional $\mathrm{P}$ was available for the plants in the solution. Therefore, there were no differences between the tested cultivars. Relative P uptake as compared to the control was 42,50 , and $26 \%$ for 'Harley Blackwell', 'La Chipper', and 'Red LaSoda', respectively. 'Red LaSoda' was the lowest in relative P uptake. In the TCP treatment, P uptake was 6.5, 3.8, and $7.7 \mathrm{mg}$ plant $^{-1}$ for the three respective varieties and was greater in 'Red LaSoda' than that in 'La Chipper'. Phosphorus mobilization from TCP by 'Red LaSoda' was also greater than that by 'La Chipper' (Figure 3). This result indicates that 'Red LaSoda' was more efficient at mobilizing P from the sparsely soluble phosphate as compared to that of the rest of the cultivars. However, 'Red LaSoda' probably had a high threshold level of P for biochemical reactions in the plants. In addition, the interaction between genotype and $\mathrm{P}$ concentration was significant at $p<0.05$ (Table 1 ). This interaction also proved that there is diversity in $\mathrm{P}$ uptake between potato genotypes based on their performances.

Phosphorus uptake from soil solution is the first step for plants to utilize an essential nutrient element. The uptake efficiency of $P$ is highly associated with the surface area of the root system that is actively absorbing nutrients [37]. Root hairs are fine in diameter and have high uptake surface area. Hence, root hairs can contribute $90 \%$ of $\mathrm{P}$ uptake in other crops such as in rye (Secale cereale L.) and wheat (Triticum aestivum L.), etc. but not in potato because of their shallow root systems and low root hair density [37]. Yamaguchi reported that potato root hairs comprised only $21 \%$ of the total root mass while root hairs in winter wheat comprised $60 \%$ [38]. In agricultural soils, beneficial fungi such as AMF (Arbuscular Mycorrhizal Fungi) can significantly increase uptake surface area and improve P uptake [39]. AMF may improve P-use efficiency of potato. However, Florida's growers need to fumigate their soil every growing season due to the favorable climate to nematodes [40]. The yearly fumigation kills all beneficial microbes including AMF. Fortunately, there is wide variation in $\mathrm{P}$ uptake rates among potato germplasm, thus making breeding for increased P-efficiency possible.

In early May 2019, we conducted a field survey of large-scale (1.2-1.6 acres per plot) field trials including a P-inefficient variety, 'Red LaSoda', on commercial potato farms in NE Florida with another potato P-efficient variety not included in this present hydroponic study. In the large-scale field study, 'Red LaSoda' developed a typical P-deficiency symptom consisting of purple leaves. The symptom was visible for $90 \%$ of the 'Red LaSoda' leaves when grown on soil with $250 \mathrm{mg} \mathrm{kg}^{-1}$ Mehlich-3 extractable $\mathrm{P}$ without $\mathrm{P}$ application, and $20 \%$ on the same soil with $\mathrm{P}$ application of $168 \mathrm{~kg} \mathrm{ha}^{-1} \mathrm{P}_{2} \mathrm{O}_{5}$. The $\mathrm{P}$ fertilizer was applied approximately one month before planting. During the month, the fertilizer applied was possibly fixed by the abundant aluminum content in the soil, thus making it difficult for the P-inefficient genotype, 'Red LaSoda', to access sufficient $P$. These deficiency symptoms were not present in the P-efficient variety, even in the zero $\mathrm{P}$ application treatment. The apparent inability of 'Red LaSoda' to access sufficient $P$ could have been due to: (1) the soil contained high aluminum and soil $\mathrm{pH}$ was around 5 in the growing season; (2) the traditional $\mathrm{P}$ fertilizer program was to apply $\mathrm{P}$ fertilizer approximately one month before planting, and hence, the P applied was fixed by aluminum; (3) 'Red LaSoda' was inefficient at mobilizing phosphates from soil rich in aluminum because $\mathrm{K}_{\mathrm{sp}}$ of aluminum phosphate $\left(\mathrm{AlPO}_{4}\right)$ is $9.84 \times 10^{-21}$ [7]. The solubility of $\mathrm{AlPO}_{4}$ is only $1 / 10,000$ of that of $\mathrm{Ca}_{3}\left(\mathrm{PO}_{4}\right)_{2}$. This field survey confirmed the results from this hydroponic study. 


\subsection{Phosphorus Utilization Efficiency}

Given sufficient $P$ supply, there was no difference among the cultivars with respect to $P$ utilization efficiency (Figure 3). P utilization efficiency increased by 28 to 76 and 20 to $80 \%$ in the $1 \mathrm{mg} \mathrm{L}^{-1} \mathrm{P}$ and TCP treatments, respectively, across all cultivars. This finding means that the $\mathrm{P}$ utilization efficiency of each variety was stable within a given $\mathrm{P}$ level. 'Red LaSoda' was the lowest in P utilization efficiency, whereas 'Harley Blackwell' was the highest (Figure 3). This result corroborates the observations that 'Red LaSoda' is not a P-efficient variety even though its mobilization from TCP is excellent (Figure 3).

As potato plants have shallow and inefficient root systems for $P$ uptake [41,42], P utilization efficiency is even more important in potato than other crops. In this study, 'Harley Blackwell' was greater in P utilization than 'La Chipper', which was greater than 'Red LaSoda', when the insoluble P as TCP was the only P source applied (Figure 3). Pefficient varieties can produce more biomass or yield per unit of $P$ utilized. For example, with TCP, 'Harley Blackwell' produced $780 \mathrm{~g}$ biomass by using $1 \mathrm{~g}$ of $\mathrm{P}$. However, the corresponding value for 'Red LaSoda' was only $461 \mathrm{~g}$. 'Harley Blackwell' had $69 \%$ more biomass than 'Red LaSoda'. The biodiversity of P utilization efficiency of potato provides an opportunity for potato breeders to breed $\mathrm{P}$ utilization efficient varieties by using elite genotypes such as 'Harley Blackwell'.

\subsection{Holistic Evaluation of Potato Varieties for P-Use Efficiency}

Based on the data shown in Figures 1-3, it is hard to differentiate the tested varieties for P-use efficiency. For example, in low-P stress, 'Harley Blackwell' had the greatest biomass and P utilization efficiency but lower P uptake than 'Red LaSoda'. 'Red LaSoda' had the greatest $\mathrm{P}$ uptake from TCP but was the smallest in both biomass and P utilization efficiency. Based on the data from Figures 1-3, the holistic scores were calculated and (Figure 5) can be classified, by using the control as 100\%, to two categories [29] as follows: (1) HS > 100, elite varieties with a high degree of tolerance to low-P stress, (2) HS < 100, varieties with a low degree of tolerance to low-P stress. Accordingly, 'Harley Blackwell' and 'La Chipper' were tolerant to low-P stress, but 'Red LaSoda' was intolerant because its $P$ utilization efficiency was the smallest. Elite varieties may be used for potato production or P-efficient potato breeding programs. In the $1 \mathrm{mg} \mathrm{L}^{-1} \mathrm{P}$ system, the tested variety's $\mathrm{P}$ uptake and P utilization efficiency can be evaluated objectively. In the TCP system, the variety's capacity for mobilizing $\mathrm{P}$ from sparsely soluble phosphates can be assessed using the traits evaluated in the system with limited water-soluble P. With the traits for P-use efficiency of potato varieties with sparsely soluble phosphates, $\mathrm{P}$ utilization efficiency of the tested varieties outweighs $P$ uptake efficiency and P mobilization efficiency. Thus, the TCP system may give a more comprehensive evaluation of the tested potato varieties and become an effective tool to identify P-efficient varieties from potato germplasm banks.

Due to the unique physical chemistry of $\mathrm{P}$, plants can only utilize a small (less than $30 \%$ ) portion of $\mathrm{P}$ fertilizer applied in the growing season with $\mathrm{P}$ application [43]. Potato vines have very shallow root systems with much fewer root hairs than other crops. Potato's P-use efficiency is even lower than most crops $[37,38]$. This low use efficiency of $P$ results in superfluous $\mathrm{P}$ fertilization for potato production and overfertilization of $\mathrm{P}$ risks the environment. Therefore, exploring and using elite genotypes from potato germplasm banks to breed P-efficient varieties is important. Exceptional genotypes would likely have both high uptake rate and efficient use of P. The holistic score concept may be helpful for potato breeders to identify P-efficient genotypes to be used as parent materials. 


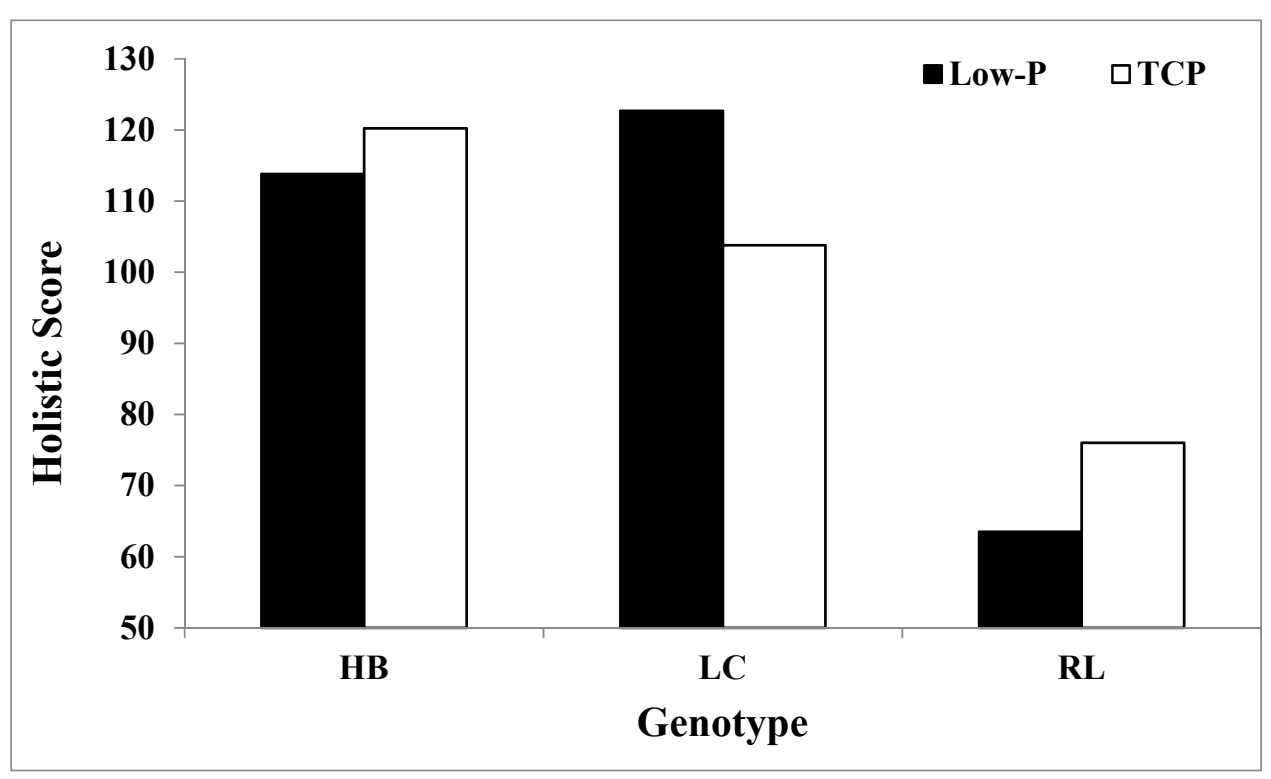

Figure 5. Holistic scores for the low-P tolerance of the potato varieties based on the measurements of P uptake, P utilization efficiency, and biomass produced by the individual varieties grown in hydroponics for 28 days. Low P: $1 \mathrm{mg} \mathrm{L} \mathrm{L}^{-1} \mathrm{P}$ as water soluble $\mathrm{P}, \mathrm{NaH}_{2} \mathrm{PO}_{4}$; and $286 \mathrm{mg} \mathrm{L}^{-1} \mathrm{TCP}$, tri-calcium phosphate, $\mathrm{Ca}_{3}\left(\mathrm{PO}_{4}\right)_{2}$ as sparsely soluble $\mathrm{P}_{\text {with }} 2286 \mathrm{mg} \mathrm{L}^{-1}$ laboratory grade $\mathrm{Ca}_{3}\left(\mathrm{PO}_{4}\right)_{2}$. HB: 'Harley Blackwell'; LC: 'La Chipper'; RL: 'Red LaSoda'. The bars are the values of $\mathrm{LSD}_{0.05,2}$ for the plant biomass of the control, low P and TCP, respectively.

\section{Conclusions}

This study showed that each of the tested varieties of potato germplasm is different in P-use efficiency. The hydroponic technique used in this study was useful for rapidly identifying potato genotypic differences in $\mathrm{P}$ uptake, $\mathrm{P}$ utilization efficiency, and biomass production during the seedling stage $(28 \mathrm{~d})$. The three potato varieties examined had distinct phenotypic responses to low-P stress. Based on these individual phenotypic responses to biomass, $\mathrm{P}$ uptake/accumulation, and $\mathrm{P}$ utilization efficiency of the genotypes, it was difficult to conclusively differentiate the varieties. Therefore, a new concept of a holistic score calculated from the individual phenotypic responses was introduced for comprehensive evaluation of potato varieties for P-use efficiency. The holistic score enabled classifying the potato germplasm into elite and ordinary cultivars for low-P growth systems. 'Harley Blackwell' was considered elite and can be directly used for low-input systems for potato production, while 'La Chipper' was semi-elite. These elite and semi-elite genotypes can be directly used as parent materials for P-efficient breeding programs. 'Red LaSoda' had an excellent mobilization capability from the sparsely soluble phosphate, TCP, and was responsive to P application. This mobilization trait of 'Red LaSoda' can be useful for breeding P-efficient potato cultivars. The use of TCP in hydroponic solution provides a convenient tool for variety evaluation to identify those genotypes that efficiently utilize bioavailable P mobilized from sparsely soluble phosphate, which is an adaptive mechanism of some cultivars to tolerate low-P growth conditions.

Author Contributions: This is part of the manuscript thesis of W.-C.L., G.L. and W.-C.L. conceptualized the experiments. W.-C.L. conducted the experiments, analyzed the data, and drafted the manuscript. Writing-review and editing, G.L., L.Z. and D.L.R. All authors subsequently contributed to editing and improving the final manuscript. All authors have read and agreed to the published version of the manuscript.

Funding: Germplasm Project received no external funding.

Institutional Review Board Statement: Not applicable.

Informed Consent Statement: Not applicable. 


\section{Data Availability Statement: Not applicable.}

Acknowledgments: Certified potato varieties: 'Harley Blackwell', 'La Chipper' and 'Red LaSoda' were obtained from the US Department of Agriculture-Agricultural Research Service, Beltsville, MD, USA. Ashok Alva, retired professor, contributed much to this manuscript. Edward Hanlon, Jonathan Denison and Emma Turner reviewed the manuscript. Bruce Schaffer helped with the SAS coding for statistical analysis.

Conflicts of Interest: The authors declare no competing interest.

\section{References}

1. Cordell, D.; Drangert, J.O.; White, S. The story of phosphorus: Global food security and food for thought. Glob. Environ. Chang. 2009, 19, 292-305. [CrossRef]

2. Mogollón, J.M.; Beusen, A.H.W.; van Grinsven, H.J.M.; Westhoek, H.; Bouwman, A.F. Future agricultural phosphorus demand according to the shared socioeconomic pathways. Glob. Environ. Chang. 2018, 50, 149-163. [CrossRef]

3. Raghothama, K.G. Phosphate acquisition. Annu. Rev. Plant. Biol. 1999, 50, 665-693. [CrossRef] [PubMed]

4. Abelson, P.H. A potential phosphate crisis. Science 1999, 283, 2015. [CrossRef] [PubMed]

5. Van Kauwenbergh, S.J.; Stewart, M.; Mikkelsen, R. World Reserves of Phosphate Rock-a Dynamic and Unfolding Story. Better Crop. 2013, 97, 18-20.

6. Soratto, R.P.; Pilon, C.; Fernandes, A.M.; Moreno, L.A. Phosphorus Uptake, Use Efficiency, and Response of Potato Cultivars to Phosphorus Levels. Potato Res. 2015, 58, 121-134. [CrossRef]

7. Shenoy, V.V.; Kalagudi, G.M. Enhancing plant phosphorus use efficiency for sustainable cropping. Biotechnol. Adv. 2005, 23, 501-513. [CrossRef]

8. Liao, X.; Liu, G.; Hogue, B.; Li, Y.; Nicholson, F. Phosphorus availability and environmental risk in potato fields in North Florida. Soil Use Manag. 2015, 31, 308-312. [CrossRef]

9. Liu, G.D.; Simonne, E.H.; Morgan, K.T.; Hochmuth, G.J.; Agehara, S.; Mylavarapu, R. 2020-2021 Vegetable Production Handbook: Chapter 2. Fertilizer Management for Vegetable Production in Florida; Publication \#CV296; University of Florida Institute of Food and Agricultural Sciences: Gainesville, FL, USA, 2020; Available online: https:/ / edis.ifas.ufl.edu/cv296 (accessed on 17 June 2021).

10. Fixen, P.E.; Bruulsema, T.W. Potato Management Challenges Created by Phosphorus Chemistry and Plant Roots. Am. J. Potato Res. 2014, 91, 121. [CrossRef]

11. Hopkins, B.G.; Ellsworth, J.W.; Bowen, T.R.; Cook, A.G.; Stephens, S.C.; Jolley, V.D.; Shiffler, A.K.; Eggett, D. Phosphorus fertilizer timing for Russet Burbank potato grown in calcareous soil. J. Plant. Nutr. 2010, 33, 529-540. [CrossRef]

12. Hopkins, B.G. Phosphorus in plant nutrition. In Handbook of Plant Nutrition, 2nd ed.; Pilbeam, D.J., Barker, A.V., Eds.; CRC Press, Taylor \& Francis Group. Ch.: Boca Raton, FL, USA, 2015; Volume 3, pp. 65-126.

13. Stark, J.C.; Love, S.L. Potato Production Systems; University of Idaho: Moscow, ID, USA, 2003. Available online: http://www.cals. uidaho.edu/edcomm/pps/about-contr.html (accessed on 17 June 2021).

14. Iwama, K. Physiology of the Potato: New Insights into Root System and Repercussions for Crop Management. Potato Res. 2008, 51, 333-353. [CrossRef]

15. Sattelmacher, B.; Marschner, H. Effects of Root-Zone Temperature on Growth and Development of Roots of Two Potato (Solanum tuberosum L.) Clones as Influenced by Plant Age, Nutrient Supply, and Light Intensity. J. Agron. Crop. Sci. 1990, 165, $190-197$. [CrossRef]

16. Mariotto-Cezar, T.C.; Coelho, S.R.M.; Christ, D.; Schoeninger, V.; de Almeida, A.J.B. Nutritional and antinutritional factors during the storage process of common bean. J. Food Agric. Environ. 2013, 11, 268-272.

17. Schenk, M.K. Nutrient efficiency of vegetable crops. Acta Hortic. 2006, 700, 21-34. [CrossRef]

18. Bais, H.P.; Weir, T.L.; Perry, L.G.; Gilroy, S.; Vivanco, J.M. The role of root exudates in rhizosphere interactions with plants and other organisms. Annu. Rev. Plant. Biol. 2006, 57, 233-266. [CrossRef]

19. Dakora, F.; Phillips, D. Root exudates as mediators of mineral acquisition in low-nutrient environments. Plant. Soil 2002, 245, 35-47. [CrossRef]

20. Gerke, J.; Beissner, L.; Romer, W. The quantitative effect of chemical phosphate mobilization by carboxylate anions on P uptake by a single root. I. The basic concept and determination of soil parameters. J. Plant. Nutr. Soil Sci. 2000, 163, 207-212. [CrossRef]

21. Hoffland, E. Quantitative-evaluation of the role of organic-acid exudation in the mobilization of rock phosphate by rape. Plant. Soil 1992, 140, 279-289. [CrossRef]

22. Alvarez-Sánchez, E.; Etchevers, J.D.; Ortiz, J.; Núñez, R.; Volke, V.; Tijerina, L.; Martínez, A. Biomass production and phosphorus uptake of potato as affected by phosphorus nutrition. J. Plant. Nutr. 1999, 22, 205-217. [CrossRef]

23. Balemi, T.; Schenk, M.K. Genotypic variation of potato for phosphorus efficiency and quantification of phosphorus uptake with respect to root characteristics. J. Plant. Nutr. Soil Sci. 2009, 172, 669-677. [CrossRef]

24. Fernandes, A.M.; Soratto, R.P. Nutrition, dry matter uptake and partitioning and phosphorus use efficiency of potato grown at different phosphorus levels in nutrient solution. Soil Sci. J. 2011, 36, 1528-1537.

25. Haynes, W.M. CRC Handbook of Chemistry and Physics, 93rd ed.; CRC Press, Taylor \& Francis Group: Boca Raton, FL, USA, 2012. 
26. Liu, G.D.; Li, Z.; Li, J. Effect on horizontally dividing the root system of wheat plants having different phosphorus efficiencies. J. Plant. Nutr. 1998, 21, 2535-2544. [CrossRef]

27. Liu, G.D.; Dunlop, J.; Phung, T.; Li, Y.C. Physiological Responses of Wheat Phosphorus-efficient and -inefficient Varietys in Field and Effects of Mixing Other Nutrients on Mobilization of Insoluble Phosphates in Hydroponics. Commun. Soil Sci. Plant. Anal. 2007, 38, 2239-2256. [CrossRef]

28. Manske, G.G.B.; Ortiz-Monasterio, J.I.; van Ginkel, M.; González, R.M.; Rajaram, S.; Molina, E.; Vlek, P.L.G. Traits associated with improved P-uptake efficiency in CIMMYT's semidwarf spring bread wheat grown on an acid Andisol in Mexico. Plant. Soil 2000, 221, 198-204. [CrossRef]

29. Liu, G.D.; Li, Y.C.; Porterfield, D.M. Genotypic Differences in Potassium Nutrition in Lowland Rice Hybrids. Commun. Soil Sci. Plant. Anal. 2009, 40, 1803-1821. [CrossRef]

30. Lee, W.C.; Liu, G.D.; Alva, A.K. Potato cultivars' specific leaf weight as an index of response to phosphate limitation. Proc. Fla. State Hortic. Soc. 2013, 126, 150-151.

31. Correa, R.M.; Brasil, J.E.; Pereira Pinto, C.A.; Faquin, V.; Reis, E.S.; Monteiro, A.B.; Dyer, W.E. A comparison of potato seed tuber yields in beds, pots and hydroponic systems. Sci. Hortic. 2008, 116, 17-20. [CrossRef]

32. Liu, G.D.; Gu, B.; Miao, S.L.; Li, Y.C.; Migliaccio, K.W.; Qian, Y. Phosphorus Release from Ash and Remaining Tissues of Two Wetland Species after a Prescribed Fire. J. Environ. Qual. 2010, 39, 1585-1593. [CrossRef]

33. O'Del, J.W. Method 365.1 Determination of Phosphorus by Semi-Automated Colorimetry; U.S. Environmental Protection Agency, Environmental Monitoring Support Laboratory: Cincinnati, OH, USA, 1993.

34. Hubbard, M.R. Statistical Quality Control for the Food Industry, 2nd ed.; Aspen Publishers, Inc.: Gaithersburg, MD, USA, 2001; ISBN 978-08-3-422093-5.

35. Lambers, H.; Shane, M.W.; Cramer, M.D.; Pearse, S.J.; Veneklaas, E.J. Root Structure and Functioning for Efficient Acquisition of Phosphorus: Matching Morphological and Physiological Traits. Ann. Bot. 2006, 98, 693-713. [CrossRef] [PubMed]

36. Wissuwa, M. Combining a modeling with a genetic approach in establishing associations between genetic and physiological effects in relation to phosphorus uptake. Plant. Soil 2005, 269, 57-68. [CrossRef]

37. Thornton, M.K.; Novy, R.G.; Stark, J.C. Improving Phosphorus Use Efficiency in the Future. Am. J. Potato Res. 2014, 91, 175-179. [CrossRef]

38. Yamaguchi, J. Measurement of root diameter in field-grown crops under a microscope without washing. Soil Sci. Plant. Nutr. 2002, 48, 625-629. [CrossRef]

39. Begum, N.; Qin, C.; Ahanger, M.A.; Raza, S.; Khan, M.I.; Ashraf, M.; Ahmed, N.; Zhang, L. Role of Arbuscular Mycorrhizal Fungi in Plant Growth Regulation: Implications in Abiotic Stress Tolerance. Front. Plant. Sci. 2019, 10, 1068. [CrossRef] [PubMed]

40. Zotarelli, L.; Dittmar, P.J.; Roberts, P.D.; Desaeger, J.; Wells, B. This is Chapter 14 of the Vegetable Production Handbook of Florida, 2020-2021 ed.; HS604; University of Florida Institute of Food and Agricultural Sciences: Gainesville, FL, USA, 2021; pp. 287-310. Available online: https: / / edis.ifas.ufl.edu/publication/CV131 (accessed on 17 June 2021).

41. Love, S.L.; Novy, R.; Corsini, D.L.; Bain, P. Variety selection and management. In Potato Production Systems; Stark, J.C., Love, S.L., Eds.; University of Idaho Agriculture Communications: Moscow, Russia, 2003; pp. 21-47.

42. Pack, J.E.; Hutchinson, C.M.; Simonne, E.H. Evaluation of controlled-release fertilizers for northeast Florida chip potato production. J. Plant. Nutr. 2006, 29, 1301-1313. [CrossRef]

43. Syers, J.K.; Johnston, A.E.; Curtin, D. Efficiency of Soil and Fertilizer Phosphorus Use. In Reconciling Changing Concepts of Soil Phosphorus Behavior with Agronomic Information; FAO Fertilizer and Plant Nutrition Bulletin No. 18; FAO: Rome, Italy, 2008. 